\title{
THE SOLID SOLUTIONS OF REBULITE AND JANKOVIĆITE IN THE PHASE SYSTEM Tl $\mathrm{Tl}_{2} \mathrm{~S}-\mathrm{As}_{2} \mathrm{~S}_{3}-\mathrm{Sb}_{2} \mathrm{~S}_{3}{ }^{\star}$
}

\author{
Tonči Balić-Žunić ${ }^{1 *}$, Yves Moëlo ${ }^{2}$, Ljiljana Karanović ${ }^{3}$, Peter Berlepsch ${ }^{4}$ \\ ${ }^{1}$ Natural History Museum, University of Copenhagen, Øster voldgade 5-7, 1350 Copenhagen K, Denmark \\ ${ }^{2}$ Institut des Matériaux Jean Rouxel, UMR 6502, CNRS, Université de Nantes, 2, rue de la Houssinière, \\ 44322 Nantes Cedex 3, France \\ ${ }^{3}$ University of Belgrade, Faculty of Mining and Geology, Laboratory of Crystallography, \\ Đušina 7, 11000 Belgrade, Serbia \\ ${ }^{4} \mathrm{CH}-4055$ Basel, Switzerland \\ *toncib@snm.ku.dk
}

\begin{abstract}
Syntheses along the $\mathrm{Tl}_{5}(\mathrm{As}, \mathrm{Sb})_{13} \mathrm{~S}_{22}$ compositional line in the $\mathrm{Tl}_{2} \mathrm{~S}-\mathrm{As}_{2} \mathrm{~S}_{3}-\mathrm{Sb}_{2} \mathrm{~S}_{3}$ phase system showed that the compositional range of rebulite extends from $T_{5} \mathrm{As}_{9.5} \mathrm{Sb}_{3.5} \mathrm{~S}_{22}$ to $\mathrm{Tl}_{5} \mathrm{As}_{7.75} \mathrm{Sb}_{5.25} \mathrm{~S}_{22}$. The $\mathrm{Sb}$-rich end-member is in equilibrium with jankovićite of the ideal composition $\mathrm{Tl}_{5} \mathrm{Sb}_{7.5} \mathrm{As}_{5.5} \mathrm{~S}_{22}$, which is considered to be the As-rich end-member of the jankovićite solid solution. The crystal structure analysis of specimens from the As and $\mathrm{Sb}$ end-members of rebulite show that the $\mathrm{Sb} / \mathrm{As}$ substitution is present in $\mathrm{Sb} 3, \mathrm{Sb} 4, \mathrm{Sb} 5, \mathrm{As} 1$ and As2 structural sites. Of them, $\mathrm{Sb} 3$ is always $\mathrm{Sb}$ dominated whereas other four vary from As- to Sb-dominated over the range of the solid solution. The change of the structural topology from jankovićite to rebulite, closely related but not identical structures, is explained through the necessity to accommodate the smaller volumes of the As coordination polyhedra, and is accomplished through unitcell twinning over the periodic $(001)_{\text {reb }}$ twin boundaries. The As end-member of the rebulite solid solution is in equilibrium with a phase of composition close to $\mathrm{Tl}_{2.4} \mathrm{Sb}_{0.68} \mathrm{As}_{7.18} \mathrm{~S}_{13}$, interpreted as imhofite.
\end{abstract}

Keywords: rebulite; jankovićite; $\mathrm{As} / \mathrm{Sb}$ solid solution; $\mathrm{Tl}_{2} \mathrm{~S}_{-}-\mathrm{As}_{2} \mathrm{~S}_{3}-\mathrm{Sb}_{2} \mathrm{~S}_{3}$ phase system

\section{ЦВРСТИ РАСТВОРИ НА РЕБУЛИТ И ЈАНКОВИК̆ИТ ВО ФАЗНИОТ СИСТЕМ $\mathrm{Tl}_{2} \mathrm{~S}-\mathrm{As}_{2} \mathrm{~S}_{3}-\mathrm{Sb}_{2} \mathrm{~S}_{3}$}

\begin{abstract}
Синтезата долж композитната линија $\mathrm{Tl}_{5}(\mathrm{As}, \mathrm{Sb})_{13} \mathrm{~S}_{22}$ во фазниот систем $\mathrm{Tl}_{2} \mathrm{~S}-\mathrm{As}_{2} \mathrm{~S}_{3}-\mathrm{Sb}_{2} \mathrm{~S}_{3}$ покажа дека ребулитната низа се движи од $\mathrm{Tl}_{5} \mathrm{As}_{9.5} \mathrm{Sb}_{3.5} \mathrm{~S}_{22}$ до $\mathrm{Tl}_{5} \mathrm{As}_{7.75} \mathrm{Sb}_{5.25} \mathrm{~S}_{22}$. Богатиот со $\mathrm{Sb}$ краен член е во рамнотежа со јанковиќит со идеален состав $\mathrm{Tl}_{5} \mathrm{Sb}_{7.5} \mathrm{As}_{5.5} \mathrm{~S}_{22}$. Најдено е дека тоа е богат со As краен член од јанковиќитниот цврст раствор. Анализата на кристалната структура на примероците од крајните членови со As и $\mathrm{Sb}$ на ребулит покажа дека кај структурните позиции $\mathrm{Sb} 3, \mathrm{Sb} 4, \mathrm{Sb} 5, \mathrm{As} 1$ и As2 е присутна супституција на Sb/As. Од нив, положбата на Sb3 е секогаш $\mathrm{Sb}$-доминантна, додека другите четири положби во низата од цврст раствор варираат од As- до Sbдоминантни. Промената на структурната топологија од јанковиќит до ребулит, чии структури се многу слични, но не идентични, е објаснета преку неопходноста од сместување на по волумен помали координациони арсенови полиедри, така што доаѓа до спарување на елементарните ќелии преку (001) reb површини на близнење. Арсенскиот краен член од ребулитниот цврст раствор е во рамнотежа со фазата со состав близок до $\mathrm{Tl}_{2.4} \mathrm{Sb}_{0.68} \mathrm{As}_{7.18} \mathrm{~S}_{13}$, интерпретиран како имхофит.
\end{abstract}

Клучни зборови: ребулит; јанковиќит; $\mathrm{As} / \mathrm{Sb}$ цврст раствор; $\mathrm{Tl}_{2} \mathrm{~S}-\mathrm{As}_{2} \mathrm{~S}_{3}-\mathrm{Sb}_{2} \mathrm{~S}_{3}$ фазен систем

\footnotetext{
- Dedicated to Academician Gligor Jovanovski on the occasion of his $70^{\text {th }}$ birthday.
} 


\section{INTRODUCTION}

Sulphosalts of As and $\mathrm{Sb}$ can show close structural similarities and sometimes form solid solution series like seligmanite-bournonite [1] or tennantite-tetrahedrite [2] through Sb/As substitution, but there are as well examples of mixed As$\mathrm{Sb}$ sulphosalts with little or no substitution, where As and $\mathrm{Sb}$ occupy distinct structural sites, like in vrbaite, $\mathrm{Hg}_{3} \mathrm{Tl}_{4} \mathrm{As}_{8} \mathrm{Sb}_{2} \mathrm{~S}_{20}$ [3]. Among $\mathrm{Tl}$ sulphosalts there are three pairs of closely structurally related, but not isostructural As-Sb sulphosalts: lorandite $\left(\mathrm{TlAsS}_{2}\right)$ - weissbergite $\left(\mathrm{TlSbS}_{2}\right)$ [4]; pierrotite $\left(\mathrm{TlAs}_{2} \mathrm{Sb}_{3} \mathrm{~S}_{8}\right)$ - parapierrotite $\left(\mathrm{TlSbS}_{8}\right)$ [5][6]; and rebulite $\left(\mathrm{Tl}_{5} \mathrm{As}_{8} \mathrm{Sb}_{5} \mathrm{~S}_{22}\right)$ - jankovićite $\left(\mathrm{Tl}_{5} \mathrm{As}_{3} \mathrm{Sb}_{10} \mathrm{~S}_{22}\right)$ [7]. Although all six named minerals show some As/Sb substitution in their structures, the stereo-chemical differences between $\mathrm{Sb}$ and As obviously have a significant structural impact, which in all three cases produces structural changes preventing a full solid solution. The actual reasons why and when the structural changes along the As-Sb compositional range occur in these three systems are not fully understood. For this, there is a lack of data over the full compositional range of the mineral pairs. Only for the lorandite-weissbergite pair this investigation has been done revealing an intermediate phase with presumably ordered As/Sb distribution [4]. In the present work the compositional range of the rebulite solid solution has been investigated and the gap to the jankovićite solid solution series determined with their crystal chemical implications.

The minerals rebulite [8] and jankovićite [9] have been so far found only in Allchar, FYR Macedonia, a world-famous locality for rare $\mathrm{Tl}$ minerals [10]. The two minerals are closely chemically related, rebulite being the As-rich and jankovićite the Sb-rich variant of the general composition $\mathrm{Tl}_{5}(\mathrm{As}, \mathrm{Sb})_{13} \mathrm{~S}_{22}$. The structural relations between them were investigated by Makovicky and BalićŽunić [7] based on the crystal structure analyses of the two minerals [8][11]. It revealed that both minerals shared common features, being composed of the layers of $\mathrm{SnS}$ archetype alternatively one and two coordination pyramids thick (B and $\mathrm{C}$, respectively) joined by layers with mirror symmetry which contain $(\mathrm{Sb}, \mathrm{As}) \mathrm{S}_{3}$ pyramids and $\mathrm{TlS}_{8}$ cubes (A on Figure 1). A periodic twinning of SnS-like layers on $(101)_{\mathrm{SnS}}$ alters the jankovićite structure into that of rebulite (Figure 1), indicating a homeotypic relationship. The "twin" slabs in jankovićite are related by inversion, whereas each second twin boundary in rebulite contains $2_{1}$ axes which increases the global symmetry from the triclinic $P \overline{1}$ to the monoclinic $P 2{ }_{1} / c$ and makes the main topological difference between the two structures [7]. This discontinuous structural change predicts that there should be a compositional gap between rebulite and jankovićite, which therefore do not represent end-members of a solid solution series but have each one a specific compositional range of $\mathrm{Sb} / \mathrm{As}$ substitution.

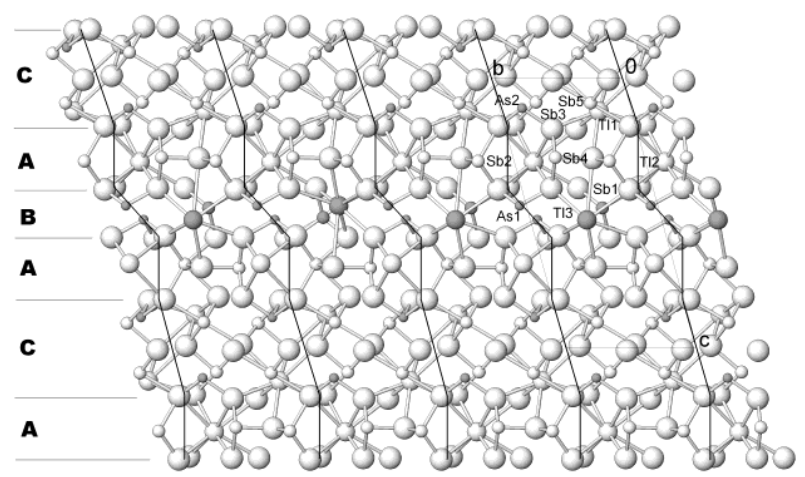

a)

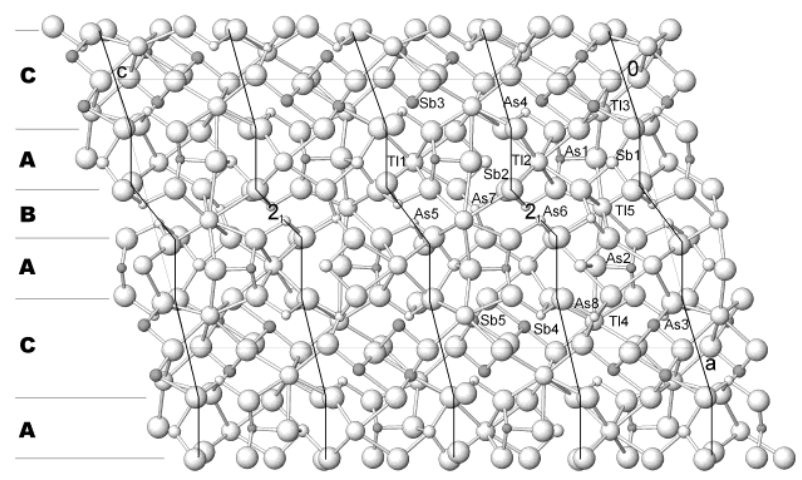

b)

Figure 1. Projections of the crystal structures of jankovićite along [100] (a) and rebulite along [010] (b) with labeling of atomic sites. The mixed sites are coloured dark. They are all characterized by a mixed Sb/As occupancy except T13/Sb1 site in jankovićite which is statistically occupied by $\mathrm{Tl}$ and $\mathrm{Sb}$ in equal proportions (a random arrangement used in the figure). The spheres in decreasing size represent $\mathrm{S}, \mathrm{Tl}, \mathrm{Sb}$ and As. Unit cells are indicated with a thin grey line. For jankovićite the origin has been translated by $1 / 2,1 / 2,1 / 2$ to make the projections equivalent. Structural layers $\mathrm{A}, \mathrm{B}$ and $\mathrm{C}$ are indicated. Thick black lines delimit the twin slabs of equivalent topology in the two structures. The "twin lamellae" are related through inversion centers in jankovićite, whereas in rebulite each second twin boundary is characterized by the $2_{1}$ axes (indicated) increasing the structural symmetry to monoclinic. After [7].

\section{EXPERIMENTAL}

The compositions along the $\mathrm{Tl}_{5}(\mathrm{As}, \mathrm{Sb})_{13} \mathrm{~S}_{22}$ have been synthesized by dry synthesis from the $\mathrm{Tl}$, As, $\mathrm{S}$ and $\mathrm{Sb}_{2} \mathrm{~S}_{3}$ p.a. reactants. The batches (Table 1) were sealed in evacuated silica tubes. The reactants were thoroughly mixed and pre- 
reacted at $200{ }^{\circ} \mathrm{C}$ for 2 months, thereafter homogenized and pressed in tablets which were again sealed in evacuated silica tubes and heated first to
$300{ }^{\circ} \mathrm{C}$ for two weeks, after which the temperature was lowered to $250{ }^{\circ} \mathrm{C}$ and heating continued for another nine weeks.

Table 1

The composition of initial samples

\begin{tabular}{lccccc}
\hline \hline Batch & $\mathrm{Tl}(\mathrm{mg})$ & $\mathrm{As}(\mathrm{mg})$ & $\mathrm{Sb}_{2} \mathrm{~S}_{3}(\mathrm{mg})$ & $\mathrm{S}(\mathrm{mg})$ & Composition \\
\hline BC9 & 132.89 & 48.72 & 176.70 & 41.70 & $\mathrm{Tl}_{5} \mathrm{Sb}_{8} \mathrm{As}_{5} \mathrm{~S}_{22}$ \\
BC8 & 137.06 & 70.34 & 136.69 & 55.91 & $\mathrm{Tl}_{5} \mathrm{Sb}_{6} \mathrm{As}_{7} \mathrm{~S}_{22}$ \\
BC7 & 139.25 & 81.68 & 115.72 & 63.36 & $\mathrm{Tl}_{5} \mathrm{Sb}_{5} \mathrm{As}_{8} \mathrm{~S}_{22}$ \\
BC10 & 141.50 & 93.37 & 94.08 & 71.04 & $\mathrm{Tl}_{5} \mathrm{Sb}_{4} \mathrm{As}_{9} \mathrm{~S}_{22}$ \\
BC11 & 146.25 & 117.95 & 48.62 & 87.19 & $\mathrm{Tl}_{5} \mathrm{Sb}_{2} \mathrm{As}_{11} \mathrm{~S}_{22}$ \\
\hline \hline
\end{tabular}

The chemical analysis was performed with a CAMECA SX50 electron microprobe (BRGMCNRS-University common laboratory, Orléans, France). The operating conditions were: accelerating voltage $20 \mathrm{kV}$, beam current $20 \mathrm{nA}$, beam size $5 \mu \mathrm{m}$, counting time $60 \mathrm{~s}$ for one spot analysis. Standards (element, emission line) are: pyrite (S $K \alpha$ ), stibnite ( $\mathrm{Sb} L \alpha$ ), AsGa (As $L \alpha$ ), lorandite (Tl $M \alpha$ ). The analysis results for the five samples are given in Table 2.

After the synthesis, parts of samples have been pulverized and investigated by X-ray powder diffraction in Huber Guinier diffractometer using $\mathrm{Cu} K \alpha$ radiation (wavelength $=1.54059 \AA$ ). In the BC9 and BC10 batches it was possible to find fragments of single crystals with rebulite structural characteristics which have been investigated with single crystal X-ray diffraction on a Bruker-AXS diffractometer featuring four-circle goniometer and the 1000 Smart CCD area detector. The experimental details for the single crystal study are listed in Table 3. The crystals gave relatively weak diffraction signals and virtually no Bragg reflections could be observed beyond $0.9 \AA$. Even with this limit, the integration of intensities resulted in a small fraction of observed reflections $\left(I>2 \sigma_{I}\right)$. Anyhow, the number was enough to obtain satisfactory refinements for the number of parameters, which is evidenced by satisfactory $R$ factors for observed reflections (Table 3). The programs used for the data collection, integration and correction, including the empirical absorption correction (SMART, SAINT and XPREP) are all Bruker AXS products and tailored for the instrument used. The crystal structure refinements were done with the Program SHELXL [12] starting from the crystal structure parameters of natural rebulite [8]. The crystal structure of $b c 10 c$ was refined with anisotropic atomic displacement parameters for all structural sites, except for the mixed Sb/As sites. In the case of $b c 9 p$ the atomic displacement factors of $\mathrm{S}$ atoms had to be kept isotropic because one of the sites acquired non-positive definite parameters in the anisotropic refinement. This is not surprising considering that the crystal did not show observed reflections over the limit of approximately $1 \AA$, so the reflections with sufficiently high $\theta$ values were practically missing from the refinement. As regards the refinement of the occupancies of the mixed $\mathrm{Sb} / \mathrm{As}$ sites, which were of the primary interest in this case, this limitation should not be of much influence because they depend primarily on the quality of intensities at low $\theta$ angles.

The crystal structure data have been deposited in the crystal structure database of the Fachinformationszentrum Karlsruhe (CSD numbers 429398 and 429399).

\section{RESULTS AND DISCUSSION}

The chemical and powder diffraction studies of the batches showed the phase compositions reproduced in Table 4 . The determined compositions would not be possible in fully homogenized and reacted samples. The appearance of the glass, chabourneite, parapierrotite, weissbergite and stibnite belongs to this category. Also, the large spread of point analyses of rebulite in BC8 suggests a not fully finished reaction (Table 2). However, although these observations witness that the reaction in the samples was not fully finalized even after about five months of thermal treatment, the predominance of rebulite and (in BC9) jankovićite, plus the phase pairs rebulite-imhofite and rebulitejankovićite in the batches that brace the compositional range of rebulite (BC11 and $\mathrm{BC} 9)$ allowed us to determine the compositional limits for rebulite and the compositional gap to jankovićite. 
Table 2

Chemical composition of various phases determined in the synthesized samples. The ranges are given in the brackets. Apfu = atoms per formula unit.

\begin{tabular}{|c|c|c|c|c|c|c|}
\hline \multirow{2}{*}{\multicolumn{2}{|c|}{$\begin{array}{l}\text { Batch } \\
\text { Phase } \\
\end{array}$}} & \multicolumn{3}{|c|}{ BC9 } & \multicolumn{2}{|c|}{$\mathrm{BC} 8$} \\
\hline & & Jankovićite & Rebulite & Weissbergite & Rebulite & Parapierrotite \\
\hline \multirow{5}{*}{$\mathrm{Wt} \%$} & $\mathrm{Tl}$ & $\begin{array}{l}33.49 \\
(32.76-34.21)\end{array}$ & $\begin{array}{l}35.20 \\
(34.22-35.91)\end{array}$ & $\begin{array}{l}51.86 \\
(50.99-52.70)\end{array}$ & $\begin{array}{l}35.60 \\
(34.52-36.56)\end{array}$ & $\begin{array}{l}15.23 \\
(13.23-17.23)\end{array}$ \\
\hline & $\mathrm{Sb}$ & $\begin{array}{l}29.29 \\
(28.57-30.12)\end{array}$ & $\begin{array}{l}21.64 \\
(21.03-22.00)\end{array}$ & $\begin{array}{l}25.03 \\
(20.59-30.49)\end{array}$ & $\begin{array}{l}16.58 \\
(12.68-21.25)\end{array}$ & $\begin{array}{l}57.80 \\
(55.21-60.43)\end{array}$ \\
\hline & As & $\begin{array}{l}13.18 \\
(12.62-13.73)\end{array}$ & $\begin{array}{l}19.47 \\
(19.14-19.96)\end{array}$ & $\begin{array}{l}4.20 \\
(0.01-7.78)\end{array}$ & $\begin{array}{l}23.85 \\
(19.68-26.85)\end{array}$ & $\begin{array}{l}0.54 \\
(0.00-1.86)\end{array}$ \\
\hline & S & $\begin{array}{l}22.49 \\
(22.17-22.61)\end{array}$ & $\begin{array}{l}23.50 \\
(23.50-23.51)\end{array}$ & $\begin{array}{l}16.53 \\
(15.94-17.21)\end{array}$ & $\begin{array}{l}24.28 \\
(23.01-24.74)\end{array}$ & $\begin{array}{l}23.76 \\
(23.54-23.89)\end{array}$ \\
\hline & Tot. & $\begin{array}{l}98.45 \\
(97.81-99.63)\end{array}$ & $\begin{array}{l}99.81 \\
(98.87-100.40)\end{array}$ & $\begin{array}{l}97.61 \\
(97.35-98.15)\end{array}$ & $\begin{array}{l}100.31 \\
(97.79-101.65)\end{array}$ & $\begin{array}{l}97.33 \\
(96.65-97.63)\end{array}$ \\
\hline \multirow{4}{*}{ Apfu } & $\mathrm{Tl}$ & 5.14 & 5.17 & 0.98 & 5.06 & 0.80 \\
\hline & $\mathrm{Sb}$ & 7.55 & 5.34 & 0.80 & 3.96 & 5.12 \\
\hline & As & 5.52 & 7.80 & 0.22 & 9.25 & 0.08 \\
\hline & $S$ & 22 & 22 & 2 & 22 & 8 \\
\hline \multicolumn{2}{|c|}{ Batch } & \multicolumn{2}{|c|}{ BC7 } & \multicolumn{2}{|c|}{ BC10 } & \\
\hline \multicolumn{2}{|c|}{ Phase } & Rebulite & Chabourneite & Rebulite & Glass & \\
\hline \multirow{5}{*}{$\mathrm{Wt} \%$} & $\mathrm{Tl}$ & $\begin{array}{l}35.07 \\
(34.36-35.46)\end{array}$ & $\begin{array}{l}24.94 \\
(24.68-25.30)\end{array}$ & $\begin{array}{l}35.20 \\
(34.88-35.56)\end{array}$ & $\begin{array}{l}31.48 \\
(30.63-33.59)\end{array}$ & \\
\hline & $\mathrm{Sb}$ & $\begin{array}{l}16.91 \\
(15.79-19.30)\end{array}$ & $\begin{array}{l}31.37 \\
(30.15-33.08)\end{array}$ & $\begin{array}{l}18.39 \\
(15.21-20.67)\end{array}$ & $\begin{array}{l}9.75 \\
(9.25-10.10)\end{array}$ & \\
\hline & As & $\begin{array}{l}23.46 \\
(21.23-24.37)\end{array}$ & $\begin{array}{l}17.36 \\
(16.13-18.25)\end{array}$ & $\begin{array}{l}22.23 \\
(20.33-24.51)\end{array}$ & $\begin{array}{l}32.83 \\
(31.07-33.43)\end{array}$ & \\
\hline & S & $\begin{array}{l}24.10 \\
(23.78-24.30)\end{array}$ & $\begin{array}{l}25.31 \\
(25.09-25.56)\end{array}$ & $\begin{array}{l}24.12 \\
(23.77-24.87)\end{array}$ & $\begin{array}{l}29.20 \\
(27.74-29.99)\end{array}$ & \\
\hline & Tot. & $\begin{array}{l}99.54 \\
(98.67-100.09)\end{array}$ & $\begin{array}{l}98.98 \\
(98.44-99.21)\end{array}$ & $\begin{array}{l}99.94 \\
(99.52-100.80)\end{array}$ & $\begin{array}{l}103.26 \\
(101.65-104.28)\end{array}$ & \\
\hline \multirow{4}{*}{ Apfu } & $\mathrm{Tl}$ & 5.02 & 2.63 & 5.04 & & \\
\hline & $\mathrm{Sb}$ & 4.07 & 5.55 & 4.42 & & \\
\hline & As & 9.16 & 4.99 & 8.68 & & \\
\hline & S & 22 & 17 & 22 & & \\
\hline \multicolumn{2}{|c|}{ Batch } & \multicolumn{3}{|c|}{ BC11 } & & \\
\hline \multicolumn{2}{|c|}{ Phase } & Rebulite & Imhofite & $X$ & & \\
\hline \multirow{5}{*}{$\mathrm{Wt} \%$} & $\mathrm{Tl}$ & $\begin{array}{l}35.81 \\
(35.14-36.57)\end{array}$ & $\begin{array}{l}33.48 \\
(32.85-34.50)\end{array}$ & $\begin{array}{l}40.92 \\
(40.76-41.12)\end{array}$ & & \\
\hline & $\mathrm{Sb}$ & $\begin{array}{l}15.40 \\
(13.70-17.09)\end{array}$ & $\begin{array}{l}5.64 \\
(5.39-5.73)\end{array}$ & $\begin{array}{l}5.19 \\
(5.10-5.26)\end{array}$ & & \\
\hline & As & $\begin{array}{l}24.68 \\
(23.50-25.90)\end{array}$ & $\begin{array}{l}36.57 \\
(35.86-37.14)\end{array}$ & $\begin{array}{l}30.86 \\
(30.72-30.95)\end{array}$ & & \\
\hline & S & $\begin{array}{l}24.37 \\
(24.16-24.57)\end{array}$ & $\begin{array}{l}28.09 \\
(27.42-29.58)\end{array}$ & $\begin{array}{l}23.83 \\
(23.76-23.87)\end{array}$ & & \\
\hline & Tot. & $\begin{array}{l}100.26 \\
(99.52-100.90)\end{array}$ & $\begin{array}{l}103.78 \\
(103.48-104.38)\end{array}$ & $\begin{array}{l}100.80 \\
(100.65-100.96)\end{array}$ & & \\
\hline \multirow{4}{*}{ Apfu } & $\mathrm{Tl}$ & 5.07 & 2.43 & 5.12 & & \\
\hline & $\mathrm{Sb}$ & 3.66 & 0.69 & 1.09 & & \\
\hline & As & 9.54 & 7.24 & 10.53 & & \\
\hline & S & 22 & 13 & 19 & & \\
\hline
\end{tabular}


Table 3

Experimental details of the single crystal $X$-ray diffraction studies on the two rebulite crystals $b c 9 p$ and bc10c from the $\mathrm{BC} 9$ and $\mathrm{BC} 10$ batches, respectively

\begin{tabular}{lll}
\hline \hline Sample & $b c 9 p-\mathrm{Tl}_{5} \mathrm{As}_{7.75} \mathrm{Sb}_{5.25} \mathrm{~S}_{22}$ & $b c 10 c-\mathrm{Tl}_{5} \mathrm{As}_{9.5} \mathrm{Sb}_{3.5} \mathrm{~S}_{22}$ \\
Crystal fragment dimensions (mm) & $0.02 \times 0.04 \times 0.06$ & $0.07 \times 0.07 \times 0.09$ \\
Space group & $\mathrm{P} 2_{1} / \mathrm{c}$ & $\mathrm{P}{ }_{1} / \mathrm{c}$ \\
Unit cell parameters: $a, b, c(\AA), \beta, V\left(\AA^{3}\right)$ & $17.49(1), 7.447(4), 32.13(2)$, & $17.464(3), 7.374(1), 32.128(6)$, \\
$\begin{array}{l}\text { Density }\left(\mathrm{gcm}^{-3}\right), \text { linear absorption } \\
\text { coefficient } \mu_{l}\left(\mathrm{~mm}^{-1}\right)\end{array}$ & $105.17(1)^{\circ}, 4039(4)$ & $105.067(4)^{\circ}, 3995(1)$ \\
$h, k, l$ limits & $4.827,30.805$ & $4.802,31.303$ \\
$\begin{array}{l}\text { No. of measured reflections, total } \\
\text { observed }\left(I>2 \sigma_{I}\right), \text { unique }\end{array}$ & $-17<h<19,-5<k<8,-33<l<35$ & $-19<h<17,-8<k<8,-35<l<35$ \\
No. of parameters & $18846,5840,1529$ & $18876,5750,2581$ \\
$R_{l}$ observed (all), $w R_{2}$ observed (all), GoF & $6.68 \%(26.39), 14.40 \%(22.11), 0.633$ & 356 \\
\hline \hline
\end{tabular}

Ta ble 4

Phase compositions (ideal formulae) of various batches. (?) are doubtful phases

\begin{tabular}{ll}
\hline \hline Batch & Phase composition \\
BC11 & Rebulite $\left(\mathrm{Tl}_{5} \mathrm{As}_{9.4} \mathrm{Sb}_{3.6} \mathrm{~S}_{22}\right)+$ imhofite $\left(\mathrm{Tl}_{2.5} \mathrm{As}_{7.5} \mathrm{Sb}_{0.7} \mathrm{~S}_{13}\right)$ \\
BC10 & Rebulite $\left(\mathrm{Tl}_{5} \mathrm{As}_{8.6} \mathrm{Sb}_{4.4} \mathrm{~S}_{22}\right)+$ glass + chabourneite $(?)$ \\
BC7 & Rebulite $\left(\mathrm{Tl}_{5} \mathrm{As}_{9} \mathrm{Sb}_{4} \mathrm{~S}_{22}\right)+$ chabourneite $\left(\mathrm{Tl}_{2.5} \mathrm{As}_{5.5} \mathrm{Sb}_{5} \mathrm{~S}_{17}\right)$ \\
BC8 & Rebulite $\left(\mathrm{Tl}_{5} \mathrm{As}_{9.1} \mathrm{Sb}_{3.9} \mathrm{~S}_{22}\right)+$ parapierrotite $\left(\mathrm{TlSb}_{5} \mathrm{~S}_{8}\right)+$ weissbergite ss. (?) + jankovićite (?) \\
BC9 & Rebulite $\left(\mathrm{Tl}_{5} \mathrm{As}_{7.7} \mathrm{Sb}_{5.3} \mathrm{~S}_{22}\right)+$ jankovićite $\left(\mathrm{Tl}_{5} \mathrm{Sb}_{7.5} \mathrm{As}_{5.5} \mathrm{~S}_{22}\right)+$ weissbergite + stibnite \\
\hline \hline
\end{tabular}

The compositional field of rebulite extends at least from $\mathrm{Tl}_{5} \mathrm{As}_{9.4} \mathrm{Sb}_{3.6} \mathrm{~S}_{22}$ to $\mathrm{Tl}_{5} \mathrm{As}_{7.7} \mathrm{Sb}_{5.3} \mathrm{~S}_{22}$ (Table 2). If we take in account the point analyses and not the averages for the samples, there are indications that the limits can go so far as $\mathrm{Tl}_{5} \mathrm{As}_{10} \mathrm{Sb}_{3} \mathrm{~S}_{22}$ for the As-rich end-member. It is in equilibrium with a phase having imhofite composition, $\mathrm{Tl}_{2.5} \mathrm{As}_{7.18} \mathrm{Sb}_{0.68} \mathrm{~S}_{13}$ on the average. Imhofite was predicted to have a variable composition which can be expressed as $\mathrm{Tl}_{3-\mathrm{x}} \mathrm{As}_{7.66+\times / 3} \mathrm{~S}_{13}$ due to the order-disorder character of its structure and a possible substitution of the $\mathrm{As}^{3+}$ for $\mathrm{Tl}^{+}$and two $\mathrm{Tl}$ vacancies [13]. The composition of the batch $\mathrm{BC} 11$ falls between the rebulite and imhofite as endmembers and shows a mixture of these two phases. In the same batch three spot analyses correspond to a phase $\mathrm{X}$ with an ideal formula $\mathrm{Tl}_{5} \mathrm{As}_{10} \mathrm{SbS}_{19}$, which might represent a new phase in the $\mathrm{Tl}_{2} \mathrm{~S}$ $\mathrm{As}_{2} \mathrm{~S}_{3}-\mathrm{Sb}_{2} \mathrm{~S}_{3}$ system, not observed before.

The Sb-richest rebulite composition is determined in sample BC9 from three spot analyses and corresponds very well to the composition obtained by X-ray diffraction on the single crystal separated from this batch. The composition of jankovićite from this sample is $\mathrm{Tl}_{5} \mathrm{Sb}_{7.5} \mathrm{As}_{5.5} \mathrm{~S}_{22}$, defining the As-richest end-member of the jankovićite solid solution. The composition of the natural sample of jankovićite was $\mathrm{Tl}_{5} \mathrm{Sb}_{10} \mathrm{As}_{3} \mathrm{~S}_{22}$ [11]. The present work did not reach so far into the Sb-rich field and we could not obtain experimental information about the Sb-rich end-member composition of this phase.

The results of the crystal structure refinements for the two rebulite crystal fragments are represented in Tables 3 and 5 (atomic parameters). As can be seen from Table 5, the compositions of the two crystals obtained by the XRD refinement are $\mathrm{Tl}_{5} \mathrm{As}_{9.2} \mathrm{Sb}_{3.8} \mathrm{~S}_{22}$ and $\mathrm{Tl}_{5} \mathrm{As}_{7.7} \mathrm{Sb}_{5.3} \mathrm{~S}_{22}$ for the $b c 10 c$ and $b c 9 p$, respectively. This lies inside the limits of the measured chemical compositions in the two samples (Table 2) and corresponds approximately to the extreme compositions of this phase. The Sb/As substitutions are active at the same structural sites (Sb3, Sb4, Sb5, As1 and As2) in both crystals. The values in Table 6 show that $\mathrm{Sb}$ content doubles in four of the sites across the solid solution from the As-rich to the Sb-rich end member, turning the originally As-dominated sites into the Sb-dominated ones. The only exception is Sb4 site where $\mathrm{Sb}$ dominates even in the As-rich endmember and increases only moderately up to the Sb-rich one. 
Table 5

The atomic parameters (coordinates, isotropic displacement parameters and occupancies)

\begin{tabular}{|c|c|c|c|c|c|c|c|c|c|c|}
\hline & \multicolumn{5}{|c|}{$b c 9 p$} & \multicolumn{5}{|c|}{$b c 10 c$} \\
\hline & $\mathrm{x}$ & $\mathrm{y}$ & $\mathrm{z}$ & $\mathrm{U}\left(\AA^{2}\right)$ & Occ. & $\mathrm{x}$ & $\mathrm{y}$ & $\mathrm{z}$ & $\mathrm{U}\left(\AA^{2}\right)$ & Occ. \\
\hline T11 & $0.3104(2)$ & $0.3072(4)$ & $0.45749(9)$ & $0.0471(8)^{*}$ & 1 & $0.3083(1)$ & $0.2990(3)$ & $0.45747(6)$ & $0.0430(6)^{*}$ & 1 \\
\hline T12 & $0.6952(2)$ & $0.1385(4)$ & $0.2869(1)$ & $0.0548(9)^{*}$ & 1 & $0.6938(1)$ & $0.1466(3)$ & $0.28750(6)$ & $0.0488(6)^{*}$ & 1 \\
\hline $\mathrm{Tl} 3$ & $0.1214(2)$ & $0.4160(4)$ & $0.06328(9)$ & $0.0428(8)^{*}$ & 1 & $0.1212(1)$ & $0.3950(3)$ & $0.06278(6)$ & $0.0435(6)^{*}$ & 1 \\
\hline $\mathrm{Tl} 4$ & $0.8984(2)$ & $0.3356(3)$ & $0.18652(8)$ & $0.0385(8) *$ & 1 & $0.8985(1)$ & $0.3255(3)$ & $0.18644(6)$ & $0.0354(5)^{*}$ & 1 \\
\hline T15 & $0.4754(2)$ & $0.3755(4)$ & $0.10989(9)$ & $0.0458(8) *$ & 1 & $0.4760(1)$ & $0.3660(3)$ & $0.11058(6)$ & $0.0401(6) *$ & 1 \\
\hline Sb1 & $0.6885(2)$ & $0.3253(5)$ & $0.4315(1)$ & $0.030(1)^{*}$ & 1 & $0.6896(2)$ & $0.3266(4)$ & $0.43194(9)$ & $0.0319(8)^{*}$ & 1 \\
\hline $\mathrm{Sb} 2$ & $0.3063(2)$ & $0.1012(5)$ & $0.3150(1)$ & $0.030(1)^{*}$ & 1 & $0.3068(2)$ & $0.0975(4)$ & $0.31588(9)$ & $0.0278(8)^{*}$ & 1 \\
\hline $\mathrm{Sb} 3$ & $0.0864(6)$ & $0.214(1)$ & $0.4284(3)$ & $0.020(2)$ & $0.66(4)$ & $0.085(1)$ & $0.208(2)$ & $0.4284(5)$ & $0.026(2)$ & $0.34(3)$ \\
\hline As3' & $0.087(2)$ & $0.171(5)$ & $0.4286(9)$ & $0.020(2)$ & $0.34(4)$ & $0.0825(8)$ & $0.171(2)$ & $0.4284(4)$ & $0.026(2)$ & $0.66(3)$ \\
\hline $\mathrm{Sb} 4$ & $0.9199(5)$ & $0.203(1)$ & $0.3259(3)$ & $0.024(2)$ & $0.80(4)$ & $0.9194(5)$ & $0.189(1)$ & $0.3262(3)$ & $0.029(2)$ & $0.72(3)$ \\
\hline As4' & $0.927(3)$ & $0.164(8)$ & $0.331(2)$ & $0.024(2)$ & $0.20(4)$ & $0.932(2)$ & $0.185(5)$ & $0.329(1)$ & $0.029(2)$ & $0.28(3)$ \\
\hline Sb5 & $0.9018(6)$ & $0.461(1)$ & $0.4248(4)$ & $0.027(2)$ & $0.68(4)$ & $0.8995(9)$ & $0.445(2)$ & $0.4271(5)$ & $0.028(2)$ & $0.34(3)$ \\
\hline As5' & $0.901(2)$ & $0.455(4)$ & $0.434(1)$ & $0.027(2)$ & $0.32(4)$ & $0.9098(7)$ & $0.443(1)$ & $0.4190(4)$ & $0.028(2)$ & $0.66(3)$ \\
\hline As1 & $0.2950(1)$ & $0.099(4)$ & $0.1671(8)$ & $0.020(2)$ & $0.35(4)$ & $0.2950(7)$ & $0.081(2)$ & $0.1669(3)$ & $0.021(2)$ & $0.74(3)$ \\
\hline Sb1' & $0.2969(5)$ & $0.052(1)$ & $0.1688(3)$ & $0.020(2)$ & $0.65(4)$ & $0.298(1)$ & $0.047(3)$ & $0.1699(7)$ & $0.021(2)$ & $0.26(3)$ \\
\hline As2 & $0.703(1)$ & $0.331(3)$ & $0.0858(7)$ & $0.022(2)$ & $0.47(4)$ & $0.7022(7)$ & $0.339(2)$ & $0.0867(4)$ & $0.021(2)$ & $0.82(3)$ \\
\hline Sb2' & $0.7018(8)$ & $0.370(2)$ & $0.0847(4)$ & $0.022(2)$ & $0.53(4)$ & $0.700(2)$ & $0.357(5)$ & $0.081(1)$ & $0.021(2)$ & $0.18(3)$ \\
\hline As3 & $0.8843(3)$ & $0.2053(7)$ & $0.04766(18)$ & $0.017(1)^{*}$ & 1 & $0.8804(3)$ & $0.1947(6)$ & $0.0470(1)$ & $0.026(1)^{*}$ & 1 \\
\hline As 4 & $0.1193(3)$ & $0.2041(8)$ & $0.2102(2)$ & $0.020(1)^{*}$ & 1 & $0.1231(3)$ & $0.1957(6)$ & $0.2120(1)$ & $0.025(1)^{*}$ & 1 \\
\hline As5 & $0.5329(4)$ & $0.2492(8)$ & $0.4891(2)$ & $0.025(2) *$ & 1 & $0.5369(3)$ & $0.2504(6)$ & $0.4891(1)$ & $0.026(1)^{*}$ & 1 \\
\hline As6 & $0.4749(3)$ & $0.1834(8)$ & $0.2606(2)$ & $0.020(1)^{*}$ & 1 & $0.4729(3)$ & $0.1766(6)$ & $0.2609(1)$ & $0.023(1)^{*}$ & 1 \\
\hline As7 & $0.4822(3)$ & $0.4283(7)$ & $0.3628(2)$ & $0.010(1)^{*}$ & 1 & $0.4822(3)$ & $0.4149(6)$ & $0.3616(1)$ & $0.021(1)^{*}$ & 1 \\
\hline As8 & $0.1144(4)$ & $0.3787(8)$ & $0.3160(2)$ & $0.026(2)^{*}$ & 1 & $0.1169(3)$ & $0.3705(6)$ & $0.3166(1)$ & $0.023(1)^{*}$ & 1 \\
\hline S1 & $-0.0066(9)$ & $0.485(2)$ & $0.1167(5)$ & $0.026(4)$ & 1 & $-0.0069(7)$ & $0.473(2)$ & $0.1175(3)$ & $0.032(3) *$ & 1 \\
\hline $\mathrm{S} 2$ & $0.1784(9)$ & $-0.019(2)$ & $0.0066(5)$ & $0.034(4)$ & 1 & $0.1815(7)$ & $-0.020(2)$ & $0.0075(3)$ & $0.030(3)^{*}$ & 1 \\
\hline S3 & $0.8131(9)$ & $0.241(2)$ & $0.3838(5)$ & $0.034(4)$ & 1 & $0.8164(7)$ & $0.234(2)$ & $0.3846(3)$ & $0.031(3)^{*}$ & 1 \\
\hline S4 & $0.8284(9)$ & $0.480(2)$ & $0.0230(5)$ & $0.031(4)$ & 1 & $0.8325(7)$ & $0.479(2)$ & $0.0237(4)$ & $0.038(3)^{*}$ & 1 \\
\hline S5 & $0.195(1)$ & $0.294(2)$ & $0.1640(5)$ & $0.040(5)$ & 1 & $0.1950(7)$ & $0.287(2)$ & $0.1640(4)$ & $0.033(3)^{*}$ & 1 \\
\hline S6 & $0.8173(9)$ & $0.449(2)$ & $0.2617(5)$ & $0.031(4)$ & 1 & $0.8171(7)$ & $0.441(2)$ & $0.2613(3)$ & $0.029(3)^{*}$ & 1 \\
\hline S7 & $0.809(1)$ & $0.137(2)$ & $0.0945(5)$ & $0.043(5)$ & 1 & $0.8055(7)$ & $0.135(2)$ & $0.0947(3)$ & $0.033(3)^{*}$ & 1 \\
\hline S8 & $0.1801(9)$ & $0.416(2)$ & $0.2630(5)$ & $0.031(4)$ & 1 & $0.1829(7)$ & $0.409(2)$ & $0.2631(3)$ & $0.029(3)^{*}$ & 1 \\
\hline S9 & $0.1923(9)$ & $0.175(2)$ & $0.3594(5)$ & $0.034(4)$ & 1 & $0.1932(6)$ & $0.169(1)$ & $0.3599(3)$ & $0.024(3)^{*}$ & 1 \\
\hline S10 & $0.990(1)$ & $0.252(2)$ & $0.4729(5)$ & $0.034(4)$ & 1 & $0.9930(7)$ & $0.248(2)$ & $0.4709(4)$ & $0.035(3)^{*}$ & 1 \\
\hline S11 & $0.981(1)$ & $0.457(2)$ & $0.3663(5)$ & $0.038(5)$ & 1 & $0.9819(7)$ & $0.451(1)$ & $0.3663(3)$ & $0.033(3)^{*}$ & 1 \\
\hline S12 & $0.4150(9)$ & $-0.016(2)$ & $0.0423(5)$ & $0.034(4)$ & 1 & $0.4127(6)$ & $-0.012(1)$ & $0.0425(3)$ & $0.025(3) *$ & 1 \\
\hline S13 & $0.5880(9)$ & $0.248(2)$ & $0.3558(5)$ & $0.031(4)$ & 1 & $0.5877(7)$ & $0.245(2)$ & $0.3565(3)$ & $0.030(3) *$ & 1 \\
\hline S14 & $0.387(1)$ & $0.532(2)$ & $0.0198(6)$ & $0.050(5)$ & 1 & $0.3856(8)$ & $0.533(2)$ & $0.0212(4)$ & $0.042(3)^{*}$ & 1 \\
\hline S15 & $0.408(1)$ & $0.262(2)$ & $0.1913(5)$ & $0.039(5)$ & 1 & $0.4046(7)$ & $0.256(2)$ & $0.1921(3)$ & $0.030(3)^{*}$ & 1 \\
\hline S16 & $0.5920(9)$ & $0.447(2)$ & $0.2224(5)$ & $0.032(4)$ & 1 & $0.5908(7)$ & $0.436(1)$ & $0.2214(4)$ & $0.029(3)^{*}$ & 1 \\
\hline S17 & $0.5929(9)$ & $0.168(2)$ & $0.0611(5)$ & $0.033(4)$ & 1 & $0.5929(7)$ & $0.162(2)$ & $0.0606(3)$ & $0.031(3)^{*}$ & 1 \\
\hline S18 & $0.4141(9)$ & $0.413(2)$ & $0.2886(5)$ & $0.036(4)$ & 1 & $0.4148(7)$ & $0.410(2)$ & $0.2889(3)$ & $0.027(3)^{*}$ & 1 \\
\hline S19 & $0.4079(9)$ & $0.199(2)$ & $0.3856(5)$ & $0.029(4)$ & 1 & $0.4095(7)$ & $0.197(2)$ & $0.3860(3)$ & $0.030(3)^{*}$ & 1 \\
\hline S20 & $0.0157(9)$ & $0.198(2)$ & $0.2777(5)$ & $0.024(4)$ & 1 & $0.0144(6)$ & $0.193(2)$ & $0.2784(3)$ & $0.027(3)^{*}$ & 1 \\
\hline S21 & $0.2932(9)$ & $0.134(2)$ & $0.0952(5)$ & $0.025(4)$ & 1 & $0.2935(6)$ & $0.145(1)$ & $0.0980(3)$ & $0.023(3) *$ & 1 \\
\hline S22 & $0.6958(9)$ & $0.295(2)$ & $0.1569(5)$ & $0.026(4)$ & 1 & $0.6935(6)$ & $0.284(2)$ & $0.1545(3)$ & $0.027(3)^{*}$ & 1 \\
\hline
\end{tabular}

* Marks the equivalent isotropic factors for the atoms that were refined anisotropically.

Observing the patterns of the $\mathrm{Sb} / \mathrm{As}$ occupancies of equivalent sites in the two structures, we can conclude that the picture changes substantially between jankovićite and rebulite (see Fig. 1). Taking the structural layers in consideration, we can see that the layer A in jankovicite houses entirely $\mathrm{Sb}$ sites, whereas in rebulite we have only half of the sites occupied solely with $\mathrm{Sb}(\mathrm{Sb} 2, \mathrm{Sb} 4)$ whereas the other half are dominantly As sites with varying Sb substitution. In the case of the B slabs, we have an interesting situation in jankovićite: $2 / 3$ of the sites are occupied by predominantly As with some $\mathrm{Sb}$ substitution (As1) whereas $1 / 3$ is the pure $\mathrm{Sb}$ site (Sb1) which is actually a site shared with 
$\mathrm{Tl} 3$ in 1:1 proportion, or in other words, a disordered site throughout the structure according to the $P \overline{1}$ group symmetry, occupied alternatively by $\mathrm{Tl}$ and $\mathrm{Sb}$.

\section{Table 6}

$S b:$ As rounded proportions in the mixed sites of the bc10c and bc9p crystals

\begin{tabular}{lll}
\hline \hline site & $b c 10 c$ & $b c 9 p$ \\
\hline Sb3 & $1.0: 2.0$ & $2.0: 1.0$ \\
Sb4 & $2.9: 1.1$ & $4.0: 1.0$ \\
Sb5 & $1.0: 2.0$ & $2.0: 1.0$ \\
As1 & $1.0: 3.0$ & $2.0: 1.0$ \\
As2 & $0.9: 4.1$ & $1.1: 0.9$ \\
\hline \hline
\end{tabular}

To the latter site corresponds the pair T15+As7 in the rebulite structure, or an ordered alteration of $\mathrm{Tl}$ and As. Contrary to jankovićite, the rest of the semi-metal sites in the B slab of rebulite are occupied entirely by As with no Sb substitution (As5, As6, As7). As regards the thickest C slab, $1 / 3$ of the semi-metal sites are dominantly or purely As-occupied in both structures (As2 in jankovićite, As3 and As4 in rebulite). The rest are pure $\mathrm{Sb}$ sites in the former ( $\mathrm{Sb} 3, \mathrm{Sb} 5$ ) or the $\mathrm{Sb} / \mathrm{As}$ sites in the latter (Sb3, Sb4, Sb5, As8).

To summarize: in jankovićite the semi-metal sites are entirely $\mathrm{Sb}$ in the A slab, in the slab $\mathrm{C}$ around $1 / 3$ of the sites are As, whereas in B slab As dominates with around 2/3 occupancy. Looking into the Sb:As proportion in rebulite slabs, it varies between 2.5:1.5 and 3.7:0.8 in slab $\mathrm{A}$, in slab $\mathrm{C}$ between 1.4:4.6 and 2.1:3.9, whereas in slab B we find only As (Table 4 and Figure 1). In both structures, thus, the content of $\mathrm{Sb}$ relative to As varies in the following sequence: $\mathrm{A}>\mathrm{C}>\mathrm{B}$, with $\mathrm{Sb}$ dominating in slab $\mathrm{A}$ and As dominating in slab $\mathrm{B}$. We assume that this is governed by the overall metrics and adjustment in sizes of the slabs which is similar for the both structures. The complete thickness of the slab package $2 \mathrm{~A}+\mathrm{B}+\mathrm{C}$ (corresponding to $d_{001}$ in jankovićite and $d_{100}$ in rebulite) changes from $16.86 \AA$ in the As-richest $b c 10 c$ to $17.07 \AA$ in natural jankovićite. This corresponds to an increase of only $1.2 \%$. The difference between $b c 10 c$ and $b c 9 p$ which lie approximately at the two ends of the rebulite solid solution range is only $0.09 \%$. The volume change, however, is from $3995 \AA^{3}$ for $V_{u c}$ in rebulite to $4114 \AA^{3}$ for $4 V_{u c}$ in jankovićite, thus around $3 \%$. Over the rebulite solid solution it changes by $1.1 \%$. It is obvious that the extension of slabs changes more than their thickness. From $b c 10 c$ to jankovićite the slabs must have changed their extension by around $2.5 \%$, and it happens entirely in direction perpendicular to the $b$ crystal axis in rebulite or $a$ crystal axis in jankovićite, which are equivalent (Fig. 1) and show a negligible change along $b$, respectively $a$, from 7.37 to $7.39 \AA$.

The main structural change between jankovićite and rebulite is, as mentioned before, the introduction of 2 operation instead of $\overline{1}$ on every second "twin" boundary. This, of course, introduces the change in the distribution of short and long interatomic contacts and coordination polyhedra along these boundaries and, as will be demonstrated, allows for the step-wise shortening of the slab extension on the change from the jankovićite to the rebulite topology. The change is best seen inside the A layers where the straight chains of Sb coordination pyramids and $\mathrm{Tl}$ coordination cubes in jankovićite running along $[110]_{\text {jank }}$ change into the zigzag arranged chain fragments (Fig. 2).

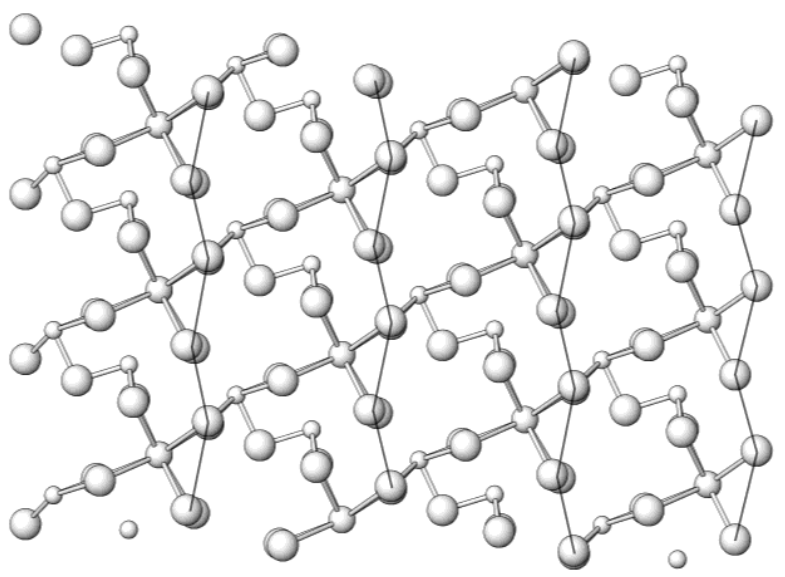

a)

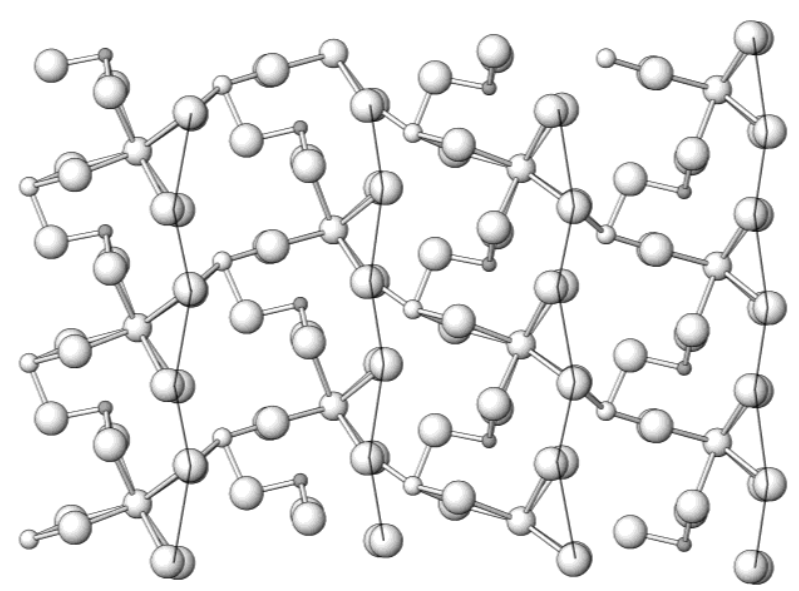

b)

Fig. 2. The side view of the A layers from jankovićite, $a$ axis vertical (a) and rebulite, $b$ axis vertical (b). Boundaries of unit-cell twin slabs indicated. After [7]. 
The alteration in the orientation of $\mathrm{Tl}$ and $\mathrm{Sb} / \mathrm{As}$ coordination polyhedra allows for the shortening of the layer extension in the direction perpendicular to the $b$ axis in rebulite. The change of the crystal structure from jankovicite to rebulite can be understood as the accommodation to the decreasing size of the coordination polyhedra of semi-metals when more $\mathrm{Sb}$ is substituted by As, which is accomplished by the periodic unit-cell twinning of slabs parallel to $(001)_{\text {reb }}$ with the consequent space shrinkage along the twin boundaries. For the details of coordinations and structure topologies the reader is directed to the article of Makovicky and Balić-Žunić [7].

The structural topology of the rebulite type was shown to be stable over the range $\mathrm{Tl}_{5} \mathrm{As}_{9.5} \mathrm{Sb}_{3.5} \mathrm{~S}_{22}-\mathrm{Tl}_{5} \mathrm{As}_{7.75} \mathrm{Sb}_{5.25} \mathrm{~S}_{22}$. Jankovićite is shown to achieve the As-richest composition of $\mathrm{Tl}_{5} \mathrm{Sb}_{7.5} \mathrm{As}_{5.5} \mathrm{~S}_{22}$. Unfortunately, no single crystals of jankovićite could be retrieved for a crystal structure study, so the crystal chemical details of the $\mathrm{Sb} / \mathrm{As}$ substitution are unknown. From the composition, however, it is evident that, even if the two As sites in the structure are completely occupied by As, still 0.75 of $\mathrm{Sb}$ must be accommodated by other structural sites. Considering the situation in rebulite and the equivalences of structural sites between the two structures we assume that the additional substitution in jankovićite is most probable on the $\mathrm{Sb} 5, \mathrm{Sb} 4$ and $\mathrm{Sb} 3$ in the decreasing order of probability. Is the presence of As necessary at the sites As1 and As2, or can jankovićite attain an As-free composition with a pure $\mathrm{Tl}-\mathrm{Sb}$ end-member, remains an open question.

Acknowledgements. We express our thanks to prof. Klaus Bente and the technical stuff of the Institute of Mineralogy and Crystallography, University of Göttingen, for their help in syntheses, and to the Alexander Humboldt Foundation for financial help. We also thank the two anonymous referees whose comments helped to improve the quality of the text.

\section{REFERENCES}

[1] I. J. Wu, R. W. Birnie, The bournonite - seligmannite solid solution. Am. Mineral., 62, 1097-1100 (1977).

[2] S. Staude, T. Mordhorst, R. Neumann, W. Prebeck, G. Markl, Compositional variation of the tennantitetetrahedrite solid solution series in the Schwarzwald ore district (SW Germany): The role of mineralization processes and fluid source. Mineral. Mag., 74(2), 309-339 (2010).

[3] M. Ohmasa, W. Nowacki, The crystal structure of vrbaite $\mathrm{Hg}_{3} \mathrm{Tl}_{4} \mathrm{As}_{8} \mathrm{Sb}_{2} \mathrm{~S}_{20}$. Z. Kristallogr., 134, 360-380 (1971).

[4] T. Balić-Žunić, E. Makovicky, Y. Moëlo, Contributions to the crystal chemistry of thallium sulphosats III. The crystal structure of lorandite $\left(\mathrm{TlAsS}_{2}\right)$ and its relation to weissbergite $\left(\mathrm{TlSbS}_{2}\right)$. N. Jb. Miner. Abh., 168, 213-235 (1995).

[5] P. Engel, M. Gostojić, W. Nowacki, The crystal structure of pierrotite, $\mathrm{Tl}_{2}(\mathrm{Sb}, \mathrm{As})_{10} \mathrm{~S}_{16}$. Z. Kristallogr., 165, 209-215 (1983).

[6] P. Engel, Die Kristallstruktur von synthetischen Parapierrotit, $\mathrm{TlSb}_{5} \mathrm{~S}_{8}$. Z. Kristallogr., 151, 203-216 (1980).

[7] E. Makovicky, T. Balić-Žunić, Contributions to the crystal chemistry of thallium sulfosalts. IV. Modular description of Tl-As-Sb sulfosalts rebulite and jankovicite. N. Jb. Miner. Abh., 174, 181-210 (1998).

[8] T. Balić-Žunić, S. Šćavničar, P. Engel, The crystal structure of rebulite, $\mathrm{Tl}_{5} \mathrm{Sb}_{5} \mathrm{As}_{8} \mathrm{~S}_{22}$. Z. Kristallogr., 160, 109-125 (1982).

[9] Lj. Cvetković, V. A. Boronikhin, M. K. Pavićević, D. Krajnović, I. Gržetić, E. Libowitzky, G. Giester, E. Tillmanns, Jankovićite, $\mathrm{Tl}_{5} \mathrm{Sb}_{9}(\mathrm{As}, \mathrm{Sb})_{4} \mathrm{~S}_{22}$, a new Tlsulfosalt from Allchar, Macedonia. Mineral. Petrol., 53, 125-131 (1995).

[10] B. Rieck, Famous mineral localities: Allchar, Macedonia. Mineralogical Record, 24(6), 437-449 (1993).

[11] E. Libowitzky, G. Giester, E. Tillmanns, The crystal structure of jankovicite, $\mathrm{Tl}_{5} \mathrm{Sb}_{9}(\mathrm{As}, \mathrm{Sb})_{4} \mathrm{~S}_{22}$. Eur. J. Mineral., 7, 479-487 (1995).

[12] G. M. Sheldrick, A short history of SHELX. Acta Cryst., A64, 112-122 (2008).

[13] T. Balić-Žunić, E. Makovicky, Contributions to the crystal chemistry of thallium sulphosalts. I. The O-D nature of imhofite. N. Jb. Miner. Abh., 165, 317-330 (1993). 